\title{
Evaluasi Peran Juru Pemantau Jentik (Jumantik) Dalam Pemberantasan Vektor Demam Berdarah Dengue (DBD) Di Kota Denpasar Tahun 2017
}

\author{
Irma Rubianti ${ }^{1}$, A.A.S.Sawitri ${ }^{1}$, I Ketut Gita ${ }^{2}$ \\ 1FETP Magister Ilmu Kesehatan Masyarakat Fakultas Kedokteran Universitas Udayana \\ ${ }^{2}$ Surveilance officer Dinas Kesehatan Kota Denpasar \\ Email: irmarubianti85@yahoo.com
}

\begin{abstract}
Abstrak
Kota Denpasar merupakan daerah endemis DBD, dengan jumlah kasus DBD menampati urutan ke-5, dan Incidence Rate menempati urutan ke-8 di Provinsi Bali. Angka bebas jentik dilaporkan tinggi oleh jumantik, akan tetapi kasus DBD juga masih tinggi sehingga perlu dilakukan evaluasi kegiatan jumantik di Kota Denpasar. Metode yang digunakan adalah evaluasi secara kualitatif meliputi input, proses, dan output. Pengumpulan data melalui wawancara dengan pedoman kuisioner pada 2 koordinator jumantik, 2 jumantik dan 1 petugas surveilans di Puskesmas Denbar II, 2 supervisor surveilans DBD, 1 kepala bidang surveilans DBD di Dinkes Kota Denpasar. Wawancara juga dilakukan pada 10 anggota masyarakat di wilayah sasaran. Analisis dilakukan secara deskriptif. Hasil evaluasi input menunjukkan sistem perekrutan kader jumantik sesuai kriteria, honor jumantik meningkat di tahun 2017 namun belum sesuai beban kerja. Evaluasi proses menunjukkan bahwa ada inkonsistensi respon jumatik dan anggota masyarakat tentang pelaksanaan tugas dan tanggung jawabnya. Di sisi lain, supervisor survailans DBD di Dinkes Kota Denpasar menyebutkan masih ada anggota masyarakat menolak pemantauan jentik. Evaluasi data sekunder menunjukkan dari 264 kasus yang dilaporkan di Dinkes Kota Denpasar pada tahun 2015, terdapat 103 kasus yang tidak berhasil ditemukan, artinya petugas surveilans melalui jumantik belum berhasil melakukan PE pada semua kasus yang dilaporkan. Selain itu masih ada anggota masyarakat yang meminta untuk dilakukan foging.
\end{abstract}

Kata Kunci: Evaluasi, Jumantik, DBD

\section{PENDAHULUAN}

Demam berdarah dengue (DBD) masih merupakan masalah kesehatan masyarakat dan menimbulkan dampak sosial maupun ekonomi. Jumlah kasus yang dilaporkan cenderung mengalami peningkatan dan daerah penyebarannya semakin meluas. Kerugian sosial yang ditimbulkan diantaranya berkurangnya usia harapan penduduk, kematian anggota kluarga dan kepanikan dalam keluarga. Dampak ekonomi secara langsung yang diderita oleh penderita DBD adalah biaya pengobatan, sedangkan dampak tidak langsungnya yaitu kehilangan waktu kerja, waktu sekolah dan biaya tidak terduga yg dikeluarkan selain biaya transportasi dan akomodasi selama dirawat.

Kota Denpasar merupakan salah satu daerah endemis DBD di Provinsi Bali yang hampir setiap tahunnya menduduki peringkat pertama dalam jumlah kasus DBD. Jumlah 
kasus DBD selama tahun 2008 di Kota Denpasar tercatat sebanyak 3.264 orang dengan kematian sebanyak 10 orang sehingga Case Fatality Rate (CFR) sebesar 0,31\%. Permasalahan utama dalam menekan angka kesakitan DBD adalah masih belum berhasilnya upaya penggerakan peran serta masyarakat dalam Pemberantasan Sarang Nyamuk (PSN) melalui gerakan 3M (menguras, menutup tempat penampungan air, mengubur barang bekas yang dapat menampung air). Sayangnya pelaksanaan program penanggulangan DBD lebih banyak dilakukan dan dikendalikan oleh pemerintah yaitu petugas kesehatan dan kurang menempatkan masyarakat seabagai mitra dalam perencanaan dan pelaksanaan program (Sali, 2009).

Tahun 2015 di kota Denpasar kasus DBD sebanyak 1.581 dengan angka kematian 14 orang, dan IR 216. Pada tahun 2016 kasus DBD 2.851 dengan angka kematian 18 orang, dan IR 434. Di Propinsi Bali, Kota Denpasar untuk kasus DBD menampati urutan ke-5, dan untuk IR menempati urutan ke-8 (Rakor Jumantik, 2017). Partisipasi masyarakat dalam PSN DBD melalui Juru Pemantau Jentik (Jumantik) dalam melakukan pemeriksaan jentik secara berkala serta menggerakkan masyarakat dalam PSN DBD. Program jumantik ini dilaksanakan sejak tahun 2004 2 Oryza Jurnal Pendidikan Biologi dan implementasinya di masing-masing daerah diserahkan kepada pemerintah daerah baik provinsi maupun kabupaten/kota (Dinkes Denpasar, 2013).

Hingga saat ini, upaya pemberantasan DBD melalui program jumantik di Kota Denpasar belum menunjukkan hasil yang optimal dimana kasus DBD masih tinggi meskipun Angka Bebas Jentik (ABJ) yang dilaporkan tinggi. Oleh sebab itu perlu dilakukan Analilsis situasi masalah terkait pelaksanaan program jumantik, sehingga akan diperoleh perioritas masalah demi tercapainya program penanggulangan DBD yang tepat.

\section{METODE}

Evaluasi secara kualitatif meliputi input, proses, dan output. Pengumpulan data melalui wawancara dengan pedoman kuisioner pada 2 koordinator jumantik, 2 jumantik dan 1 petugas surveilans di Puskesmas Denbar II, 2 supervisor surveilans DBD, 1 kepala bidang surveilans DBD di Dinkes Kota Denpasar. Wawancara juga dilakukan pada 10 anggota masyarakat di wilayah sasaran. Analisis dilakukan secara deskriptif.

\section{HASIL DAN PEMBAHASAN INPUT}

1. Masalah Sumber Daya Manusia (Ketenagaan) 
Dari hasil wawancara dengan petugas surveilans DBD yang berada di dinas Kesehatan Kota Denpasar, bahwa sistem perekrutan kader Jumantik telah berlangsung sesuai kriteria Jumantik. Semua Jumantik memiliki ijasah minimal SMU sederajat, berasal dari tiap Banjar bersangkutan, dan tidak memiliki pekerjaan tetap umumnya adalah ibu rumah tangga. Untuk menyakini informasi tersebut, peneliti menanyakan kembali terkait kriteria perekrutan jumantik kepada petugas surveilans DBD, jumantik dan koordinator jumantik yang ada di wilayah kerja Puskesmas Denbar I dan hasil wawancaranya menyatakan bahwa seratus (100 \%) responden menjawab perekrutan jumantik sudah sesuai dengan kriteria yang ditentukan.

\section{Pendanaan}

Dana diperoleh dari alokasi APBD dengan pembagian disesuaikan terhadap kebutuhan program. Disamping pendanaan APBD juga terdapat beberapa sumber dana yang tidak mengikat, seperti swadaya masyarakat. Dana yang dianggarkan telah dihitung dari keseluruhan aspek operasional kegiatan Jumantik, yang dimulai dari perencanaan program hingga hasil dari program tersebut dalam satu tahun berjalannya program. Hasil dari wawancara menunjukkan tidak adanya keluhan terhadap ketersediaan dana terkait biaya operasional selama program Jumantik berlangsung, khususnya insentif bagi Jumantik.

Dari segi pembiayaan, tahun 2017 honor meningkat, untuk koordinator jumantik dari Rp.1.800.000 menjadi Rp.2.010.000, dan untuk jumantik dari Rp.900.000 menjadi Rp.1.005.000. Hal ini menunjukkan bahwa Pemerintahan Kota Denpasar memberikan perhatian yang serius terkait pencegahan dan penggulangan DBD. Dengan ditingkatkannya honor untuk jumantik, diharapkan dapat bekerja lebih baik dan maksimal dibanding sebelumnya.

Sesuai dengan peraturan Gubernur Bali tanggal 18 November 2016 Nomor 67 tahun 2016 tentang upah minimum kabupaten/Kota bahwa UMR Kota Denpasar adalah sebesar Rp.2.173.00. Honor jumantik saat ini masih di bawah UMR, padahal Jumantik bekerja dari pukul 07.30 - 14.00 WITA dan setiap harinya jumantik harus memeriksa jentik ke 30 rumah.

Tugas dan tanggung jawab jumantik, diantaranya: (a) Membuat rencana/jadwal kunjungan rumah dan tempat-tempat umum yang ada di wilayah kerjanya, (b) memberikan penyuluhan (perorangan/kelompok) dan melaksanakan pemantauan jenti di rumahrumah/bangunan sebanyak 30 
rumah/hari/orang, (c) memiliki peran dalam menggerakan dan mengawasi masyarakat dalam Program Pemberantasan Sarang Nyamuk (PSN) Demam Berdarah Dengue (DBD), (d) Membuat catatan/rekapitulasi hasil pemeriksaan jentik setiap hari kerja., (e) Melaporkan hasil pemeriksaan jentik ke Koordinator Jumantik setiap hari kerja dan (f) Memotivasi masyarakat dalam memperhatikan tempat-tempat potensial perkembangbiakan nyamuk penular DBD (Depkes RI, 2007)

Beban kerja yang bergitu berat dengan honor yang masih di bawah UMR akan menimbulkan masalah, seperti tidak maksimalnya jumantik dalam melakukan tugas dan tanggung jawabnya.

\section{PROSES}

1. Masalah pendataan Angka Bebas Jentik $(\mathrm{ABJ})$.

Hingga saat ini, upaya pemberantasan DBD melalui program jumantik di Kota Denpasar belum menunjukkan hasil yang optimal dimana kasus DBD masih tinggi meskipun Angka Bebas Jentik (ABJ) yang dilaporkan oleh jumantik tinggi. Hal ini dapat dilihat pada tabel tabel 1 .

Tabel 1. Angka Bebas Jentik (ABJ) dengan Kasus DBD di Kota Denpasar Tahun 2013- 2015

\begin{tabular}{|c|c|c|c|c|c|c|c|c|c|}
\hline \multirow[t]{2}{*}{ Wilayah } & \multicolumn{4}{|c|}{$\begin{array}{l}\text { Tahun } \\
2013\end{array}$} & \multicolumn{2}{|c|}{$\begin{array}{l}\text { Tahun } \\
2014\end{array}$} & \multicolumn{3}{|c|}{$\begin{array}{l}\text { Tahun } \\
2015\end{array}$} \\
\hline & $\begin{array}{l}\text { ABJ } \\
(\%)\end{array}$ & Kasus & $\begin{array}{l}\text { Kem- } \\
\text { atian }\end{array}$ & $\begin{array}{l}\text { ABJ } \\
(\%)\end{array}$ & Kasus & $\begin{array}{l}\text { Kema- } \\
\text { tian }\end{array}$ & $\begin{array}{l}\text { ABJ } \\
(\%)\end{array}$ & Kasus & $\begin{array}{l}\text { Kema- } \\
\text { tian }\end{array}$ \\
\hline $\begin{array}{l}\text { Denpasar } \\
\text { Barat }\end{array}$ & 93,50 & 484 & 1 & 97,06 & 635 & 2 & 97,08 & 522 & 2 \\
\hline $\begin{array}{l}\text { Denpasar } \\
\text { Utara }\end{array}$ & 94,37 & 417 & 0 & 97,31 & 329 & 1 & 96,53 & 233 & 2 \\
\hline $\begin{array}{l}\text { Denpasar } \\
\text { Timur }\end{array}$ & 95,40 & 279 & 1 & 97,66 & 254 & 3 & 97,14 & 273 & 3 \\
\hline $\begin{array}{l}\text { Denpasar } \\
\text { Selatan }\end{array}$ & 91,29 & 586 & 1 & 97,18 & 619 & 1 & 96,93 & 548 & 6 \\
\hline
\end{tabular}

Dari hasil wawancara diperoleh melakukan observasi secara langsung ketika informasi bahwa responden $100 \%$ menjawab jumantik bekerja, sehingga menjadi jumatik sudah melakukan tugas dan tanggung kelemahan dalam penelitian ini. jawabnya sesuai dengan prosedur yang Selain itu juga peneliti menanyakan ditentukan. Akan tetapi peneliti tidak kepada petugas surveilans DBD terkait 
hambatan jumantik yang dijumpai dilapangan pada waktu mereka melakukan pemantauan jentik kerumah penduduk. Informasi yang diperoleh bahwa kesadaran masyarakat akan pentingnya menjaga lingkungan sekitar masih kurang. Hal ini dikuatkan dari hasil wawancara dengan beberapa jumatik, yang mengatakan bahwa, mereka tidak dapat bekerja secara maksimal untuk memantau jentik, karena terkadang pada waktu mereka turun kerumah-rumah, ada beberapa orang yang masih enggan rumahnya untuk dipantau jeniknya, sehingga jumantik hanya memantau tempat perindukan jentik yang berada diluar rumah, sedangkan jentik di dalam rumah tidak dapat dipantau oleh jumantik.

Untuk memperkuat informasi terkait tugas dan tanggung jawab jumantik, peneliti kemudian melakukan kunjungan ke rumah penduduk dan mewawancarai 10 orang penduduk yang menjadi lokasi pelaksanaan program jumatik. Dari hasil wawancara yang dilakukan, 8 dari 10 responden memberikan informasi bahwa jumantik setiap minggu selalu datang memantau jentik ke rumah, tidak hanya di luar rumah melainkan juga di dalam rumah dan diberikan penyuluhan serta abate oleh jumantik.

Berikut Kutipan wawancara dengan salah satu respoden terkait penyuluhan.

5 Oryza Jurnal Pendidikan Biologi
"Pernah bu, waktu itu anak saya lagi demam tinggi dan jumantiknya menyarankan agar anak saya di bawa ke Puskesmas, dan saya disuruh untuk selalu menguras bak mandi minimal 2xseminggu.

Berbeda dengan informasi yang diperoleh dari 2 orang responden, yang menyatakan bahwa mereka dikunjungi oleh jumantik tapi hanya 1 bulan 1 kali, dan setiap jumantik datang, mereka kadang hanya memantau dari luar tanpa masuk ke dalam rumah untuk memantau jentik. Kutipan wawancara dengan salah satu respoden terkait pemantauan jentik diluar dan di dalam rumah.

"Kadang-kadang mereka masuk, tapi kadang juga mereka hanya memantau dari luar dan membagikan abate, padahal saya tidak keberatan lho bu kalau mereka juga masuk ke rumah saya".

Untuk kegiatan pemberantasan sarang nyamuk (PSN), semua responden memberikan informasi bahwa jumantik sangat berperan, hal ini terbukti dari kegiatan serentak (Gertak) dalam PSN yang dilakukan oleh jumantik dan masyarakat setiap hari Jum'at dan sabtu.

Hasil dari jawaban responden, sebagian besar memberikan informasi bahwa sebagian besar jumantik sudah menjalankan tugas dan tanggung jawab mereka. Akan tetapi ada informasi yang diperoleh dari Volume 8 Nomor 2 November 2019 
beberapa responden menunjukkan bahwa oleh Rumah sakit ke Dinas Kesehatan yang

masih ada jumantik yang tidak menjalankan tugasnya dengan baik. Hal ini akan berpengaruh terhadap Angka Bebas Jentik $(\mathrm{ABJ})$ yang dilaporkan oleh jumantik.

2. Masalah Penyelidikan Epidemiologi yang dilakukan oleh Jumatik

Penyelidikan Epidemiologi (PE) yang dapat ditemukan pada kasus yang dilaporkan diteruskan ke Puskesmas Denpasar Barat I tidak semuanya dapat dilakukan. Pada tabel berikut ini disajikan data jumlah kasus yang di PE dan kasus yang tidak ditemukan pada waktu dilakukan PE. Pada tabel 2 disajikan jumlah kasus DBD yang berhasil dilakukan PE

Tabel 2. Jumlah kasus DBD yang yang dilakukan PE di Puskesmas Denpasar Barat I Tahun 2015

\begin{tabular}{llrcc}
\hline No & Desa/ Kelurahan & \multicolumn{2}{c}{ Jumlah kasus DBD } & $\begin{array}{c}\text { Persentase Kasus } \\
\text { DBD yang di PE }\end{array}$ \\
\hline & & Di PE & Tidak Ketemu & \\
\hline 1 & Desa Padangsambian Kaja & 71 & 21 & $77,17 \%$ \\
\hline 2 & Desa Tegal Kerta & 50 & 17 & $74,63 \%$ \\
\hline 3 & Desa Tegal Harum & 38 & 15 & $71,70 \%$ \\
\hline 4 & Kelurahan Padangsambian & 84 & 37 & $69,42 \%$ \\
\hline 5 & Kelurahan Pemecutan & 20 & 13 & $60,61 \%$ \\
\hline & Jumlah & 264 & 103 & $71,93 \%$ \\
\hline
\end{tabular}

Dari 264 kasus yang dilaporkan, 103 kasus tidak ditemukan. Hal ini berarti bahwa hanya 161 kasus yang dapat dilakukan Penyelidikan Epidemiologi (PE). Kasus yang tidak segera dilakukan PE 1X24 jam, akan menyebabkan suatu masalah, karena mata rantai penularan DBD dalam hal ini terkait vektor nyamuk tidak mampu diputus dalam waktu yang cepat dan tepat. Vektor nyamuk DBD akan terus menjangkit pada penduduk, yang pada akhirnya kasus DBD akan tetap tinggi. Kasus yang tidak dilakukan PE juga akan berdampak pada deteksi dan pengobatan dini kasus. Sehingga kadangkala kasus yang ditemukan, sudah terlambat mendapatkan pengobatan, dan pada akhirnya meninggal. Dari hasil wawancara yang dilakukan pada petugas surveilans di Dinas kesehatan Kota Denpasar, bahwa laporan kasus yang diterima Volume 8 Nomor 2 November 2019 
berasal dari RSUD dan 17 Rumah sakit swasta yang ada di Kota Denpasar.

Dari hasil wawancara dengan beberapa tenaga surveilans DBD dan tenaga jumantik, menyatakan bahwa hal ini disebabkan karena dari data kasus surveilans yang dilaporkan dari Rumah Sakit, alamat pasien suspek kasus DBD berbeda dengan alamat sebenarnya, sehingga ketika jumantik dari Puskesmas atau dari Dinas kesehatan turun kelapangan untuk melakukan penyelidikan epidemiologi (PE) tidak menemukan pasien tersebut. Alamat yang diberikan pada waktu mengunjungi layanan kesehan kemungkinan adalah alamat keluarga tempat si pasien tersebut tinggal sementara, sedangkan alamat sebenarnya mungkin pasien tersebut bertempat tinggal di luar Kota Denpasar.

Dari hasil wawancara dengan beberapa tenaga surveilans DBD dan tenaga jumantik, menyatakan bahwa hal ini disebabkan karena dari data kasus surveilans yang dilaporkan dari Rumah Sakit, alamat pasien suspek kasus DBD berbeda dengan alamat sebenarnya, sehingga ketika jumantik dari Puskesmas atau dari Dinas kesehatan turun kelapangan untuk melakukan penyelidikan epidemiologi (PE) tidak menemukan pasien tersebut. Alamat yang diberikan pada waktu mengunjungi layanan kesehan kemungkinan adalah alamat keluarga tempat si pasien tersebut tinggal

\begin{tabular}{l|l}
7 & Oryza Jurnal Pendidikan Biologi
\end{tabular} sementara, sedangkan alamat sebenarnya mungkin pasien tersebut bertempat tinggal di luar Kota Denpasar.

\section{Masalah Pelaksanaan Foging}

Dari hasil wawancara dengan dengan petugas surveilans DBD dan jumatik di Kota Denpasar, informasi yang diperoleh bahwa kebanyakan penduduk/ kelurahan/ Desa, meminta wilayahnya untuk dilakukan foging, padahal kriteria untuk dilakukan foging tidak terpenuhi. Penduduk sering mendesak Kepala Desa/ Kelurahan/ Dinkes untuk melakukan foging. Hal ini menjadi permasalahan, ketika masyarakat selalu beranggapan bahwa dengan melakukan foging, mereka tidak akan mengalami DBD. Peran jumantik dan tenaga kesehatan sangat diperlukan dalam merubah pola berfikir masyarakat, sehingga masyarakat akan sadar pentingnya menjaga lingkungan sekitar.

Proses pelaksanaan foging, Dinkes Kota Denpasar menyerahkan sepenuhnya pada pemerintah Desa/Kelurahan. Hal ini disebabkan karena yang mengetahui kebutuhan dan kapan desanya akan difoging adalah pemerintahan Desa itu sendiri. Tenaga foging harus harus dilatih oleh tenaga dari Dinkes, dan takaran untuk obat fogingnya harus dibawah pemantauan tenaga dari Dinas Kesehatan Kota Denpasar. Kendala yang dihadapi yaitu, kadangkala desa meminta Volume 8 Nomor 2 November 2019 
untuk difoging tanpa kriteria dan alasan yang jelas, sehingga pendanaan untuk foging cenderung tidak efektif.

\section{OUTPUT.}

Proses Pencegahan dan penggulangan DBD menjadi perioritas utama disebabkan karena, dari hasil wawancara dengan beberapa responden yang merupakan tenaga surveilans DBD di Dinkes Kota Denpasar dan jumantik, mengatakan bahwa kesadaran masyarakat akan pentingnya menjaga lingkungan sekitar masih kurang. Selain itu masyarakat juga kurang kooperatif ketika jumantik datang untuk memantau jentik kerumah penduduk

Untuk mengatasi masalah ini, pada tahun 2017 Walikota Denpasar mencanangkan suatu program yang disebut dengan program "Gemapetik" (Gerakan Mandiri Pemantau Jentik). Program Gemapetik yaitu program yang mengharuskan di setiap rumah ditunjuk salah satu anggota keluarganya untuk dijadikan jumantik mandiri. Kemudian jumantik mandiri ini akan dibuatkan SK dari Kelurahan. Jumantik mandiri akan diajarkan dan dilatih oleh tenaga dari Dinkes Kota Denpasar dalam hal terkait penyakit DBD dan penggunaan abate baik cara memakai dan kapan harus digunakan. Dari jumantik mandiri diharapkan mampu memantau rumahnya sendiri terkait keberadaan jentik, baik yang berada didalam rumah maupun yang berada di sekitar rumah. Jumantik yang ditugaskan langsung berkoordinasi dengan jumantik mandiri, sehingga masalah-masalah terkait pencegahan dan penaggulangan DBD dapat teratasi.

Program gemapetik diharapkan mampu menurunkan angka kejadian DBD di Kota Denpasar. Adanya kerjasama yang baik antara jumantik dan masyarakat akan menghasilkan data Angka Bebas Jentik (ABJ) yang sesuai dengan keadaan sebenarnya (representatif), sehingga penaggulangan dan pencegarah penyakit DBD dapat dilakukan secara cepat dan tepat.

\section{KESIMPULAN}

Dinas Kesehatan Kota Denpasar untuk saat ini, masih banyak dijumpai kendala dalam pencegahan dan penaggulangan DBD pada peningkatan upaya pemberantasan vektor penular penyakit DBD melalui program juru pemantau jentik (jumantik). Masalah yang masih dijumpai diantaranya adalah masalah pendataan Angka Bebas Jentik (ABJ) yang dilakukan oleh jumantik. Penerimaan masyarakat terhadap kegiatan jumantik masih rendah sehingga menghambat peran jumantik. Selain itu tupoksi jumantik masih melebihi kapasitasnya. 


\section{DAFTAR PUSTAKA}

Chriswardani S. Metode Penentuan Prioritas

Masalah. Bahan Kuliah Perencanaan

dan Evaluasi Kesehatan, Fakultas

Kesehatan Masyarakat, Universitas

Diponegoro.

Depkes RI. 2007. Petunjuk Teknis Pemberantasan Sarang Nyamuk Demam Berdarah Dengue (PSN DBD) oleh Juru Pemantau Jentik (Jumantik). Jakarta : Kementerian Kesehatan Republik Indonesia, Direktorat Jenderal Pengendalian Penyakit dan Penyehatan Lingkungan, Direktorat Pengendalian Penyakit Bersumber Binatang.

Dini, Amah Majidah Vidyah,dkk. 2010. Faktor Iklim Dan Angka Insiden Demam Berdarah Dengue Di Kabupaten Serang. Fakultas Kesehatan Masyarakat, Universitas Indonesia. Makara, Kesehatan, Vol. 14, No. 1, Juni 2010: 37-45.

Dinkes Denpasar. 2013. Buku Pedoman Jumantik. Program Pencegahan dan Penanggulangan Penyakit Menular Tahun 2013. Denpasar : Dinas Kesehatan Kota Denpasar

Direktorat Kesehatan Dan Gizi Masyarakat.2006.Kajian Kebijakan Penanggulangan (Wabah) Penyakit
Menular Studi Kasus DBD. Badan Perencanaan Pembangunan Nasional Tahun 2006.

Kota Denpasar.2014.Profil kesehatan Kota Denpasar Tahun 2014.Pemerintahan Kota Denpasar, Bali.

Paramita Djati Anggun.2010. Faktor Risiko Demam Berdarah Dengue Di Kecamatan Wonosari Kabupaten Gunungkidul Provinsi DIY. Prosiding Seminar Nasional Kesehatan Jurusan Kesehatan Masyarakat FKIK UNSOED Purwokerto, 31 Maret 2012.

Paputungan Mohamad Hasrul.2015.Faktor Risiko Yang Berhubungan Dengan Kejadian Demam Berdarah Dengue Di Wilayah Kerja Puskesmas Gogagoman Kecamatan Kotamobagu Barat Kota Kotamobagu. Program Pascasarjana. Fakultas Kesehatan Masyarakat Universitas Sam Ratulangi Manado.

Sali, I Wayan. 2009. Faktor yang Mempengaruhi Kinerja Jumantik Dalam Memantau Jentik Aedes Aegypti di Kecamatan Denpasar Selatan Kota Denpasar Tahun 2009. Jurnal Skala Husada Volume 8 Nomer 2 September 2011:143-149 